\title{
An Empirical Study of Relationship Between University Innovation Team Members' Psychological Contract and Organizational Commitment
}

\author{
Lili Wang, Xiaojun Lu and Jia Li \\ School of Public Administration and Law \\ Dalian University of Technology, DUT \\ Dalian, China \\ Wangll@dlut.edu.cn
}

\begin{abstract}
This paper discusses about the influence mechanism of university innovation team member's psychological contract on organizational commitment under the micro environment of teamwork. Using data from 514 university innovation team members, the results show that (1)the three dimensions of team's responsibility have cross effects on the three dimensions of the responsibility of the members,(2)the team's responsibility and member's responsibility both have direct positive impact on organizational commitment, and team's responsibility has indirect impact on organizational commitment through on member's responsibility.
\end{abstract}

Keywords- psychological contract; organizational commitment; innovation team in university

\section{INTRODUCTION}

University innovation team plays an important role in scientific and technological innovation and growth of creative talent. As a new form of university research organization, university innovation team is a major force of the national scientific and technological innovation system. University innovation team is initiated by a team leader of University researchers, composited by a group of different professional skills of various complementary, to a common research object, with innovation spirit and teamwork spirit. In these teams, team member's contribution is the key to the team's outputs. Psychological contract plays an important role as their psychological link between team members, will directly affect the members' attitude and investment to the whole team.Therefore,in order to improve the relationship between team members and enhance their job performance, this study tested the relationship between the university innovation team members' psychological contract and organizational commitment through the method of empirical research.

\section{THEORETICAL ANALYSIS}

\section{A. Structure and Internal Relations of Psychological Contract}

The initial concept of psychological contract is considered to be an undocumented, implicit agreement or expectation in employment between the two sides of the contract. This concept is further discussed by later scholars, gradually formed a broad and narrow definition of psychological contract. The broad definition emphasized the subjective understanding of the exchange of obligations between employee and organization, the prime representatives were Herriot, Pemberton, Guest, and they were known as the classical school [1] [2]. Narrow definition emphasized the staff party's one-way expectations from the organization, the prime representatives were Rousseau, Morrison, Robinson, and they were called "Rousseau school"[3] [4].

The narrow definition was adopted by many researchers because it has a clear boundary, and solves the empirical study's difficult faced by classical school. Based on this narrow definition, this study defined university innovation team members' psychological contract as a team member's subjective perception about "team's responsibility" and "member's responsibility". Based on the commitment of the team goals achieving, university innovation team members' psychological contract includes responsibilities of team and team members perceived by the team members under the cooperative relationship but not the employment relationship.

The contents of team responsibility and members' responsibility are different. From the basic meaning and characteristics of university innovation team members' psychological contract, the innovation team is very strong goal oriented. Team members have strong demand of selfdevelopment, they quest for the sense of achievement, knowledge acquisition and health concern make pure economic interest secondary to them.Joining the team is a conscious behavior with objective purpose, the members place strong emotion to their team.Their responsibility of team and the responsibility of themselves will be connected very naturally with team building goals. That is, the commitment basic of team member's psychological contract is to consciously abide team rules, make the contribution for the team, cooperate with other members and ,maintain team work atmosphere during the process of team goal achievement. Therefore, university innovation team member's psychological contract will pay more attention to the goal, development and the living and working environment, but the specific attention to team's responsibility and member's responsibility may be differences. 
The internal structure of the psychological contract, in the strict sense, team's responsibility and member's responsibility influence each other.This dynamic change will undoubtedly bring great difficulties to the research. However, most researchers recognized such an explanation: in the real organizations, the relationship between employee and organization is not totally reciprocal,and organizations always play a decisive role, employees will adjust their attitude and behavior after seeing, hearing or feeling the conditions and commitments provided by organizations. So, in the relationship between the team's responsibility and member's responsibility, team member will show his/her responsibility after he/she perceives the responsibility fulfilled by the organization [5].Similarly, in the psychological contract of university innovation team member, the team fulfillment responsibility in the first place, it will affect the performance of the responsibility of the members, and then affect the establishment and maintenance of university innovation team member's psychological contract. Therefore, this study proposes the first hypothesis:

Hypothesis 1:In the psychological contract of university innovation team members, team's responsibility has positive effect on member's responsibility, and different dimensions of team' responsibility have cross effects on different dimensions' of member's responsibility.

\section{B. Organizational Commitment of University Innovation Team Members and Its Relationship with Psychological Contract}

The organizational commitment of university innovation team member is a affirmative psychological set on the organization, including team loyalty, sense of identity and active participation in the activities of the organization which can be called "internalization of behavior norms".

According to Allen and Meyer's (1990) definition, organizational commitment has three dimensions, namely, affective commitment, continuous commitment and normative commitment. The affective commitment, refers to employees' emotional attachment to, identification with, and involvement in, the organization. The continuance commitment refers to commitment based on the costs that employees associate with leaving the organization. Finally, the normative commitment refers to employees' feelings of obligation to remain with the organization[6].University innovation team member's organizational commitment includes at least the affective commitment and normative commitment. So, is there any interest exchange relationship between university innovation team members and team? The answer is yes. Although this benefit is not purely economic interests, more than an exchange of spiritual interests. For example, if a member leaves the team, it may not be more conducive to his/her own development than in a team environment.So, university's innovation team members' organizational commitment should also include continuous commitment. In order to differ from the continuous commitment definition of Allen and Meyer, this paper named it as continuance commitment.

Some research show that psychological contract should be the basis for the formation of organizational commitment.
Because of individual cognition, contrast and faith for the responsibilities of parties, leads to individual has different commitment type and degree to organization(Rousseau, 1995;Morrison \& Robinson, 1997) [5][7]. Psychological contract contains "team's responsibility" and "member's responsibility" embodies the organization and member benefit relation. If psychological contract is well performed, it will increase member's degree of organization loyalty, identity and activity participation ,strengthening his/her "internalization of behavior norms",namely to the enhancement of organizational commitment. Therefore, the psychological contract can have a direct impact on organizational commitment, and the impact is positive. Therefore, this study proposes the second hypothesis:

Hypothesis 2: University innovation team members' psychological contract has positive effect on their organizational commitment.

Hypothesis2-1: Team's responsibility of university innovation team members' psychological contract has positive effect on their organizational commitment.

Hypothesis2-2: Member's responsibility of university innovation team members' psychological contract has positive effect on their organizational commitment.

\section{RESEARCH METHODS}

\section{A. Instrument}

The instruments include the university innovation team members' psychological contract scale and organizational commitment scale. Two scales are designed according to the following steps:

1) The collection scale items: we reviewed literatures, and collected the domestic and international relevant psychological contract scale (Rousseau, 2000; Chen, etc., 2003) [8][9] and Organizational Commitment Scale(Meyer,1993; Ling, 2000)[10][11]for reference. The University innovative team members' suggestions about the content of team's responsibility, member's responsibility and organizational commitment were collected by in-depth interviewed and surveyed with open questionnaire.

2) Initial questionnaire: we classified of the collected items, and screened out the most important items according to their frequency order. Then, the relevant professionals were asked to assess the results, and submit the recomposed opinions about items. Through the foresaid works, we obtained the initial questionnaire.

3)Pretest: 150 questionnaires were send to the team members of Dalian University of Technology randomly, a total of 116 questionnaires were considered valid, the response rate is $77.3 \%$. We used item-total correlation and reliability analysis,and the content validity of scales was test by professionals. During the test, 7 items were deleted, which were 2 items from team's responsibility scale, 2 items from member's responsibility scale and 1 item from organizational commitment scale. The formal questionnaire includes 16 items for team's responsibility, 13 items for member's 
responsibility and 12 items for organizational commitment. Five-point Likert scale that ranged from" $1=$ almost never" to "5=almost always" was used.

\section{B. Sample}

The formal survey selected 30 "985 engineering" universities to collect data. We conducted the questionnaire survey to 29 university innovation teams in Dalian University of Technology University, and 463 questionnaire were collected, meanwhile, we send emails to the 329 university innovation team members in another 29 universities to invite them respond our questionnaires. Finally, a total of 514 questionnaires (64.9\% response rate) were considered valid.

In a total of 514 participants, seventy-two percent of participants were male; twenty-eight percent were female. Seventeen percent of participants were professors, twentyeight percent were associate professors, thirty-eight percent were lecturers, and the rest were assistant, post-doctoral and doctoral students. 447 participants $(87 \%)$ were academic backbone in the team.

\section{HYPOTHESIS TEST}

In order to test the hypothesis 1 and hypothesis 2 , firstly, we conducted validity and reliability analysis of scales to ensure the quality of data. Secondly, the impact of team's responsibility on members' responsibility and two responsibilities on organizational commitment were tested by multiple regression analysis. Because that the internal relationship may be existed in the construct of psychological contract, and caused the indirect impact of team's responsibility on organizational commitment, we explored the influence path of psychological contract on organizational commitment with structural equation modeling.

\section{A. Validity and Reliability Analysis of the Scales}

1) Factor analysis: Exploratory factor analysis(EFA) and confirmatory factor analysis(CFA) were applied to test the construct validity. We randomly split the whole sample into two roughly equal parts. The first half contained 257 subjects and a EFA was conducted with SPSS 13.0, and the second half had 257 subjects and a CFA was conducted withLESREL8.7.

EFA was used ti discover the factor structure of psychological contract and organizational commitment respectively. Factors were extracted with a principal components method with a Promax rotation. The "eigenvalues greater than one" were extracted, and a minimum factor loading of 0.40 was required for an item to be interpreted as part of a factor, and double loadings item was deleted. The results showed that one item was deleted form the team's responsibility and one item was deleted form organizational commitment. The results of EFA was shown in Table.1.
TABLE I. THE RESULTS OF EXPLORATORY FACTOR ANALYSIS (N1=257)

\begin{tabular}{|c|c|c|c|c|c|c|}
\hline \multirow{8}{*}{$\begin{array}{c}\text { Team' } \\
\text { s responsibil } \\
\text { ity }\end{array}$} & \multicolumn{2}{|c|}{$\begin{array}{c}\text { Achieving perfo } \\
\text { rmance }\end{array}$} & \multicolumn{2}{|c|}{$\begin{array}{c}\text { Supporting } \\
\text { development }\end{array}$} & \multicolumn{2}{|c|}{$\begin{array}{l}\text { Concerning about } \\
\text { life quality }\end{array}$} \\
\hline & Item & Loading & Item & Loading & Item & Loading \\
\hline & 2 & 0.88 & 10 & 0.85 & 13 & 0.81 \\
\hline & 5 & 0.84 & 7 & 0.84 & 15 & 0.81 \\
\hline & 4 & 0.71 & 9 & 0.65 & 14 & 0.70 \\
\hline & 3 & 0.66 & 11 & 0.64 & 16 & 0.57 \\
\hline & 1 & 0.65 & 12 & 0.51 & & \\
\hline & 6 & 0.52 & & & & \\
\hline $\begin{array}{c}\text { Eigenvalue / } \\
\text { Variation } \\
\end{array}$ & \multicolumn{2}{|c|}{$7.715 / 51.432 \%$} & \multicolumn{2}{|c|}{$1.732 / 11.547 \%$} & \multicolumn{2}{|c|}{$1.288 / 8.587 \%$} \\
\hline \multirow{6}{*}{$\begin{array}{c}\text { Member' s } \\
\text { responsibilit } \\
\mathbf{y}\end{array}$} & \multicolumn{2}{|c|}{$\begin{array}{l}\text { Maintaining } \\
\text { team }\end{array}$} & \multicolumn{2}{|c|}{$\begin{array}{l}\text { Active contributio } \\
\text { n }\end{array}$} & \multicolumn{2}{|c|}{$\begin{array}{l}\text { Complying with } \\
\text { norms }\end{array}$} \\
\hline & 1 & 0.90 & 7 & 0.84 & 11 & 0.90 \\
\hline & 4 & 0.88 & 8 & 0.72 & 10 & 0.88 \\
\hline & 5 & 0.87 & 6 & 0.72 & 12 & 0.68 \\
\hline & 2 & 0.62 & 9 & 0.60 & 13 & 0.47 \\
\hline & 3 & 0.52 & & & & \\
\hline $\begin{array}{c}\text { Eigenvalue / } \\
\text { Variation }\end{array}$ & \multicolumn{2}{|c|}{$6.861 / 52.779 \%$} & \multicolumn{2}{|c|}{$1.260 / 9.691 \%$} & \multicolumn{2}{|c|}{$1.142 / 8.783 \%$} \\
\hline \multirow{5}{*}{$\begin{array}{l}\text { Organizatio } \\
\text { nal } \\
\text { commitment }\end{array}$} & \multicolumn{2}{|c|}{$\begin{array}{l}\text { Continuance } \\
\text { commitment }\end{array}$} & \multicolumn{2}{|c|}{$\begin{array}{l}\text { Continuance com } \\
\text { mitment and norm } \\
\text { ative commitment }\end{array}$} & \multicolumn{2}{|c|}{$\begin{array}{l}\text { Affective } \\
\text { commitment }\end{array}$} \\
\hline & 1 & 0.86 & 7 & 0.75 & 10 & 0.95 \\
\hline & 2 & 0.84 & 5 & 0.71 & 9 & 0.94 \\
\hline & 4 & 0.64 & 6 & 0.70 & 12 & 0.68 \\
\hline & & & 8 & 0.65 & 11 & 0.67 \\
\hline $\begin{array}{l}\text { Eigenvalue / } \\
\text { Variation }\end{array}$ & \multicolumn{2}{|c|}{$5.734 / 52.129 \%$} & \multicolumn{2}{|c|}{$1.249 / 11.350 \%$} & \multicolumn{2}{|c|}{$1.071 / 9.736 \%$} \\
\hline
\end{tabular}

A CFA was utilized for sample 2, the results as shown in Table. 2.

TABLE II. RESULTS OF THE CONFIRMATORY FACTOR ANALYSIS (N2=257)

\begin{tabular}{cccccccc}
\hline & $\chi^{2} / d \boldsymbol{f}$ & $\boldsymbol{G F I}$ & $\boldsymbol{A G F I}$ & $\boldsymbol{N N F I}$ & $\boldsymbol{C F I}$ & $\boldsymbol{R M S E A}$ & SRMR \\
\hline $\begin{array}{c}\text { Team' s } \\
\text { responsibility }\end{array}$ & 1.42 & 0.97 & 0.93 & 0.99 & 0.99 & 0.050 & 0.025 \\
\hline $\begin{array}{c}\text { Member's } \\
\text { responsibility }\end{array}$ & 2.24 & 0.96 & 0.91 & 0.99 & 0.99 & 0.070 & 0.021 \\
\hline $\begin{array}{c}\text { Organizationa } \\
\text { l commitment }\end{array}$ & 1.22 & 0.98 & 0.95 & 0.99 & 0.99 & 0.061 & 0.017 \\
\hline
\end{tabular}

GFI, NNFI, CFI and AGFI were greater than $0.90, R M S E A$ and $S R M R$ is less than 0.08, show that the three models are fitted well with the original data.

Exploratory analysis and confirmatory factor analysis results show that the scale has reasonable construct validities.

2) Reliability analysis: Table.3 represents the means, standard deviations, and coefficient of internal consistency of dimensions. Each dimension's Cronbach 'alpha coefficients were higher than 0.70 , indicates that the scale has reasonable reliability coefficients. 
TABLE III. MEANS, STANDARD DEVIATIONS AND COEFFICIENT OF INTERNAL CONSISTENCY OF DIMENSIONS(N=514)

\begin{tabular}{|c|c|c|c|c|}
\hline & Variables & M & SD & Cronbach' $\alpha$ \\
\hline \multirow{3}{*}{$\begin{array}{c}\text { Team's respo } \\
\text { nsibility }\end{array}$} & $\begin{array}{l}\text { Achieving perform } \\
\text { ance }\end{array}$ & 4.28 & 0.62 & 0.89 \\
\hline & $\begin{array}{c}\text { Supporting develo } \\
\text { pment }\end{array}$ & 4.41 & 0.67 & 0.87 \\
\hline & $\begin{array}{c}\text { Concerning about } 1 \\
\text { ife quality }\end{array}$ & 4.23 & 0.76 & 0.92 \\
\hline \multirow{3}{*}{$\begin{array}{l}\text { member' s r } \\
\text { esponsibility }\end{array}$} & Maintaining team & 4.59 & 0.56 & 0.88 \\
\hline & Active contribution & 4.50 & 0.53 & 0.86 \\
\hline & $\begin{array}{c}\text { Complying with no } \\
\text { rms }\end{array}$ & 4.70 & 0.44 & 0.86 \\
\hline \multirow{3}{*}{$\begin{array}{c}\text { Organization } \\
\text { al commitme } \\
\text { nt }\end{array}$} & $\begin{array}{c}\text { Continuance comm } \\
\text { itment }\end{array}$ & 4.04 & 0.87 & 0.73 \\
\hline & $\begin{array}{c}\text { Normative commit } \\
\text { ment }\end{array}$ & 4.38 & 0.66 & 0.85 \\
\hline & $\begin{array}{c}\text { Affective commitm } \\
\text { ent }\end{array}$ & 4.33 & 0.70 & 0.81 \\
\hline
\end{tabular}

\section{B. Regression Analysis}

Stepwise regression analyses were performed to test the relationship between the variables. The impact of team's responsibility on member's responsibility was analyzed (see Table. 4), and the impact of team's responsibility and member's responsibility on three organizational commitment dimensions was analyzed (see Table. 5)

TABLE IV. THE RELATIONSHIP BETWEEN TEAM' S RESPONSIBILITY AND MEMBER' S RESPONSIBILITY $(\mathrm{N}=514)$

\begin{tabular}{|c|c|c|c|c|}
\hline $\begin{array}{c}\text { Dependen } \\
\text { t variable }\end{array}$ & $\begin{array}{c}\text { Independent vari } \\
\text { able }\end{array}$ & $\begin{array}{c}\text { Standardized } \\
\text { Beta }\end{array}$ & $\mathbf{T}$ & $\operatorname{Adj} R^{2}$ \\
\hline \multirow{2}{*}{$\begin{array}{l}\text { Maintainin } \\
\text { g team }\end{array}$} & Supporting devel & 0.620 & $11.108 * *$ & \multirow[b]{2}{*}{0.520} \\
\hline & $\begin{array}{c}\text { Concerning abou } \\
\text { t life quality }\end{array}$ & 0.132 & $2.355^{*}$ & \\
\hline \multirow{2}{*}{$\begin{array}{l}\text { Active cont } \\
\text { ribution }\end{array}$} & $\begin{array}{c}\text { Achieving perfor } \\
\text { mance }\end{array}$ & 0.434 & $6.852 * *$ & \multirow[b]{2}{*}{0.377} \\
\hline & $\begin{array}{l}\text { Supporting devel } \\
\text { opment }\end{array}$ & 0.223 & $3.531 * *$ & \\
\hline \multirow{2}{*}{$\begin{array}{l}\text { Complying } \\
\text { with norms }\end{array}$} & $\begin{array}{c}\text { Supporting devel } \\
\text { opment }\end{array}$ & 0.540 & $9.504 * *$ & \multirow{2}{*}{0.499} \\
\hline & $\begin{array}{c}\text { Achieving perfor } \\
\text { mance }\end{array}$ & 0.209 & $3.681 * *$ & \\
\hline
\end{tabular}

$*^{*} P<0.01,{ }^{*} P<0.05$

The results of regression analysis showed that the fulfillment of team responsibility of university innovation team will influence members' responsibility. Supporting development of team's responsibility have significant positive effects on three dimensions of member's responsibility, achieving performance of team's responsibility have significant positive effects on active contribution and complying with norms of member's responsibility, and Concerning about life quality of team's responsibility has significant positive effect on maintaining team of member's responsibility. Overall, the research hypothesis 1 was supported.
TABLE V. THE RELATIONSHIP BETWEEN PSYCHOLOGICAL CONTRACT AND ORGANIZATIONAL COMMITMENT(N=514)

\begin{tabular}{|c|c|c|c|c|}
\hline $\begin{array}{l}\text { Dependent } v \\
\text { ariable }\end{array}$ & $\begin{array}{c}\text { Independent vari } \\
\text { able }\end{array}$ & $\begin{array}{c}\text { Standardized } \\
\text { Beta }\end{array}$ & $\mathbf{T}$ & $\operatorname{Adj} R^{2}$ \\
\hline \multirow{3}{*}{$\begin{array}{c}\text { Continuance } \\
\text { commitmen } \\
\mathbf{t}\end{array}$} & $\begin{array}{c}\text { Concerning about } \\
\text { life quality }\end{array}$ & 0.279 & $4.103 * *$ & \multirow{3}{*}{0.300} \\
\hline & Maintaining team & 0.164 & $2.497 *$ & \\
\hline & $\begin{array}{c}\text { Supporting devel } \\
\text { opment }\end{array}$ & 0.178 & $2.258^{*}$ & \\
\hline \multirow{4}{*}{$\begin{array}{l}\text { Normative c } \\
\text { ommitment }\end{array}$} & $\begin{array}{c}\text { Supporting devel } \\
\text { opment }\end{array}$ & 0.285 & $4.851 * *$ & \multirow{4}{*}{0.648} \\
\hline & Concerning about & 0.332 & $6.582 * *$ & \\
\hline & $\begin{array}{c}\text { life quality } \\
\text { Complying with n } \\
\text { orms }\end{array}$ & 0.201 & $4.404 * *$ & \\
\hline & $\begin{array}{c}\text { Achieving perfor } \\
\text { mance }\end{array}$ & 0.102 & $2.001 *$ & \\
\hline \multirow{4}{*}{$\begin{array}{l}\text { Affective co } \\
\text { mmitment }\end{array}$} & $\begin{array}{c}\text { Supporting devel } \\
\text { opment }\end{array}$ & 0.420 & $7.197 * *$ & \multirow{4}{*}{0.646} \\
\hline & $\begin{array}{c}\text { Active contributio } \\
\mathbf{n}\end{array}$ & 0.279 & $5.727 * *$ & \\
\hline & $\begin{array}{l}\text { Achieving perfor } \\
\text { mance }\end{array}$ & 0.186 & $3.601 * *$ & \\
\hline & Maintaining team & 0.242 & $4.071 * *$ & \\
\hline
\end{tabular}

$*_{*} P<0.01,{ }^{*} P<0.05$

The regression analysis indicated that the different dimensions of team's responsibility and members' responsibility have both significant positive effects on organizational commitment, especially have stronger predicted effects on normative commitment and affective commitment.Hypothesis 2 was supported.

The results show that on the one hand, when team members needs of good interpersonal environment, humanities, career development support and material security of achieving the goals are met, they will exhibit higher team commitment and identity. On the other hand, the team members formed self responsibility cognition, they will maintain team external image and internal relationship, and achieve the team's goal and continue development, and keep the team running order and the individual team membership, as the results, they will strengthen the dependence and identity of the organization.

\section{Analysis of Structural Equation Model}

Tab. 4 shows that the fulfillment of team's responsibility directly influences member's responsibility, and Tab.5 shows the team's responsibility and member's responsibility both have direct positive impact on organizational commitment.The results indicates that the team's responsibility not only directly affect organizational commitment, but also indirectly affect organizational commitment through on member's responsibility. The structural equation modeling was used to tested the relationship among team's responsibility, member's responsibility and organizational commitment (see Figure.1). 


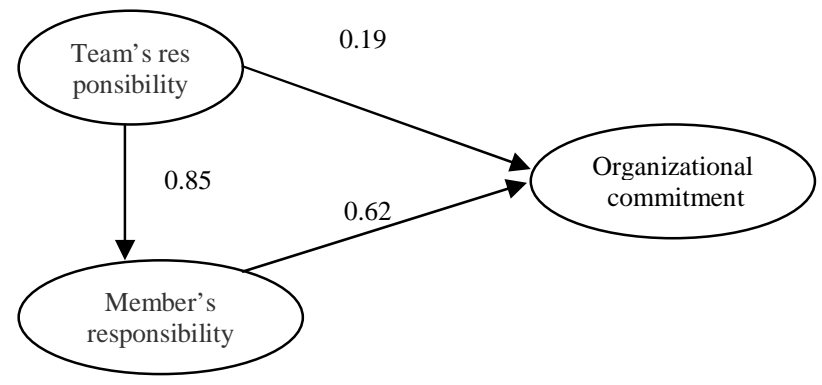

FIGURE I. EFFECT OF PSYCHOLOGICAL CONTRACT ON ORGANIZATIONAL COMMITMENT

The fit index of the model were $\chi^{2} / d f=3.74$, NNFI $=0.96, C F I=0.97, G F I=0.91, A G F I=0.87, R M S E A=0.072$; $S R M R=0.037$, The results reflects a good fitting model.

The test results show that the team's responsibility and member's responsibility both have direct positive impact on organizational commitment,and team's responsibility has indirect impact on organizational commitment through on member's responsibility. The total effect of team's responsibility on organizational commitment is $0.717(0.62 \times$ $0.85+0.19=0.717)$. Team's responsibility has stronger positive effect on organizational commitment than member's responsibility, namely the team identity and commitment of university innovation team members is more affected by their perceived team responsibility fulfillment degree.

\section{CONCLUSION}

University innovation team member's psychological contract is a team member's cognition, contrast and faith for the team and individual responsibilities. In the psychological contract, the differences of the fulfillment of team's responsibility and member's responsibility will cause the different commitment type and degree to organization.The empirical research confirms that the university innovation team members' psychological contract has significant positive effect on organizational commitment. Different from the previous similar research[12][13], this study found a new path of impact which is "team's responsibility $\rightarrow$ member's responsibility $\rightarrow$ organizational commitment", rather than team's responsibility and member's responsibility influence on organizational commitment isolately. The results of structural equation model test shows that the team member perceived team's responsibility is an important source of team members on the team's identity and input,it can directly affect organizational commitment,and strengthen the team members their responsibility, to further improve the organizational commitment.
This study confirms the impact of the university innovation team member's psychological contract on organizational commitment. Some management strategies should be adopt, including shared vision construction, team culture creation, a scientific incentive mechanism establishment, democratic and fair internal management implementation, and smooth communication mechanism establishment. These management strategies can promote the construction and maintenance of university innovation team members' psychological contract improve organizational commitment.

\section{ACKNOWLEDGMENT}

Humanities and Social Sciences Planning Fund of Ministry of Education (11YJA630128); Dalian Science and Technology Plan - Soft Science Project (2011D12ZC128).

\section{REFERENCES}

[1] P. Herriot, C. Pemberton, "Contracting careers," Human Relations, vol.49, pp.757-790,1995.

[2] E. D.Guest, "On meaning, metaphor and psychological contract: A response to rousseau," Journal of Organizational Behavior, vol.19,pp.673-677,1998.

[3] D. M.Rousseau, "Psychological and implied contracts in organizations," Employee Responsibilities and Rights Journal, vol.2,pp.121-139,1989.

[4] S. L. Robinson, E. W.Morrison, "Psychological contracts and OCB: The effect of unfulfilled obligations on civic virtue behavior," Journal of Organizational Behavior, vol.16,pp.289-298,1995.

[5] D. M.Rousseau, "Psychological Contracts in Organizations: Understanding Written and Unwritten Agreement,'Thousand Oaks, CA: SAGE Publications, 1995.

[6] J. A. Natalie,P.M. John ,"The measurement and antecedents of affective, continuance and normative commitment," Journal of Occupational Psychology,vol.63,pp.1-18,1990.

[7] E. W.Morrison, S. L. Robinson, "When employee feel betrayed: A model of how psychological contract violation develops," Academy of Management Review, vol.22,pp.226-256,1997.

[8] D. M.Rousseau, "Perceived legitimacy and unilateral contract changes,"Journal of Organizational Behavior, vol.4,pp.25-29,2000.

[9] J.Z. Chen, W.Q. Ling, L.L. Fang. "Context, dimension, type of the psychological contract," Psychological Science Progress,vol.11,pp.437445,2003.

[10] J. P.Meyer, N. J.Allen, C. A.Smith, "Commitment to organizations and occupations: Extension and test of a three-component conceptualization,'Journal of Applied Psychology, vol.78,pp.538551,1993 .

[11] W.Q. Ling,Z.C. Zhang, L.L. Fang. "Chinese worker structure model of organizational commitment ,'Journal of Management ,vol.3,pp.7681,2000 .

[12] P. Wang."Based on the empirical study of the psychological contract of employees' organizational commitment," Master Dissertation of Zhejiang University,2007.

[13] J. Chen. "Organizational change in the study on the relationship between the employees' psychological contract and organizational commitment ,"Master Dissertation of Zhejiang University,2008. 